\title{
Exploring the views of healthcare professionals on increasing smoking cessation advice for patients
}

ShuYing $\mathrm{Ho}^{*}$, Hannah McGee, Noel G McElvaney, Frank Doyle

From International Conference for Healthcare and Medical Students 2012

Dublin, Ireland. 2-3 November 2012

\section{Background}

Smoking cessation advice provided by healthcare professionals can be effective in increasing smoking cessation among patients. Any successful intervention will require staff knowledge of local barriers to implementation. However, the views of Irish healthcare professionals in increasing provision of smoking cessation advice and these barriers are unknown. The aim of this qualitative study is to explore the views of Irish healthcare professionals on barriers in increasing smoking cessation advice for patients in a large Irish teaching university hospital.

\section{Methods}

Semi-structured interviews were conducted with 16 healthcare professionals recruited in Beaumont Hospital.

\section{Results}

The main barriers identified are patient and staff attitude, time and service constraints, information not readily available and issues on smoke-free campus policy.

\section{Conclusions}

Our results identified barriers expressed by Irish healthcare professionals in providing smoking cessation advice to patients. This supports the need to implement a multicomponent hospital-based intervention to increase the rate of provision of smoking cessation advice in patients by healthcare professionals.

Published: 30 January 2013

\footnotetext{
* Correspondence: shuyingho08@gmail.com

Royal College of Surgeons in Ireland, Dublin, Ireland
}

doi:10.1186/1753-6561-7-S1-P6

Cite this article as: Ho et al:: Exploring the views of healthcare professionals on increasing smoking cessation advice for patients. BMC Proceedings 2013 7(Suppl 1):P6.
Submit your next manuscript to BioMed Central and take full advantage of:

- Convenient online submission

- Thorough peer review

- No space constraints or color figure charges

- Immediate publication on acceptance

- Inclusion in PubMed, CAS, Scopus and Google Scholar

- Research which is freely available for redistribution 